\title{
GH and the cardiovascular system: an update on a topic at heart
}

\author{
Jörgen Isgaard · Michele Arcopinto • \\ Kristjan Karason • Antonio Cittadini
}

Received: 2 April 2014/Accepted: 4 June 2014/Published online: 28 June 2014

(C) The Author(s) 2014. This article is published with open access at Springerlink.com

\begin{abstract}
In this review, the importance of growth hormone $(\mathrm{GH})$ for the maintenance of normal cardiac function in adult life is discussed. Physiological effects of GH and underlying mechanisms for interactions between $\mathrm{GH}$ and insulin-like growth factor I (IGF-I) and the cardiovascular system are covered as well as the cardiac dysfunction caused both by GH excess (acromegaly) and by GH deficiency in adult hypopituitary patients. In both acromegaly and adult GH deficiency, there is also increased cardiovascular morbidity and mortality possibly linked to aberrations in GH status. Finally, the status of the GH/IGF-I system in relation to heart failure and the potential of $\mathrm{GH}$ as a therapeutic tool in the treatment of heart failure are reviewed in this article.
\end{abstract}

Keywords Growth hormone - Insulin-like growth factor · Cardiovascular · Heart

\section{Introduction}

Besides well-recognized effects such as promoting longitudinal bone growth in childhood and exerting a number of

J. Isgaard ( $\square)$

Laboratory of Experimental Endocrinology, Department of Internal Medicine, Sahlgrenska Academy, University of Gothenburg, Gröna Stråket 8, 41345 Göteborg, Sweden e-mail: jorgen.isgaard@medic.gu.se

M. Arcopinto · A. Cittadini

Department of Internal Medicine, Cardiovascular and Immunological Sciences, Federico II University, Naples, Italy

K. Karason

Department of Cardiology, Sahlgrenska University Hospital, Göteborg, Sweden metabolic effects, growth hormone (GH) has an important role for the development of a normal heart [1]. GH also has a major impact on maintaining the structure and function of the normal adult heart $[1,2]$. Apart from stimulating cardiac growth and possibly also contractility, GH/IGF-I interacts with the vascular system and has a role in the regulation of vascular tone and thereby peripheral resistance. Also central effects including modulation of sympathetic outflow contribute to regulation of peripheral resistance [3].

The myocardium and vessels express IGF-I [4-6] and functional receptors for both GH [7-9] and IGF-I [10, 11], and IGF-I production is up-regulated in response to GH [5]. Thus, there are possibilities of direct actions of GH as well as endocrine or autocrine/paracrine effects of IGF-I on the cardiovascular system. However, although interaction of the GH/IGF-I axis and the cardiovascular system has been extensively studied, the relative importance of direct effects of GH and local and endocrine IGF-I remains unclear.

\section{Vascular effects of GH and IGF-I}

Regulation of peripheral resistance

Both GH and IGF-I have been suggested to have a regulatory role for peripheral resistance, although it is often difficult to differentiate between direct effects of GH and effects mediated by IGF-I. Evidence to suggest rapid vasoactive effects of IGF-I includes the finding that intravenous administration of IGF-I decreases mean arterial blood pressure within a few minutes in normal rats [12, 13]. In a human study, stroke volume and cardiac output were increased, but blood pressure unchanged a few hours after a single injection of IGF-I [14]. Moreover, in patients 
with chronic heart failure (CHF), IGF-I infusion increased cardiac output and decreased peripheral resistance within a time span of $2 \mathrm{~h}$ [15]. A similar effect of GH was seen after $24 \mathrm{~h}$ when serum IGF-I was concomitantly increased [16]. These data suggest that IGF-I has potent, acute functional effects on the cardiovascular system. In a more recent study, it was shown in healthy subjects that GH directly increased forearm blood flow paralleled by a decrease in peripheral resistance [17]. Moreover, these changes were suggested to be mediated by stimulation of endothelial function through the NO system. However, the effect was not seen until $4 \mathrm{~h}$ after $\mathrm{GH}$ infusion, and it is possible that $\mathrm{GH}$ actions were mediated by local production of IGF-I in the periphery.

Despite accumulating evidence supporting the vasodilating effects of IGF-I, there have only been a few studies addressing the role of IGF-I in more long-term, physiological regulation of peripheral resistance. Lembo et al. [18] showed that mice with a mutant IGF-I allele and $30 \%$ of wild-type IGF-I levels present in all tissues, and serum have elevated blood pressure. In analogy, transgenic mice with a liver-specific knock-out of IGF-I and an $80 \%$ decrease of circulating IGF-I also display a significant elevation of blood pressure, indicating that a decrease in endocrine-acting IGF-I results in an elevation of blood pressure [19].

Several studies suggest that the vascular actions of IGF-I may be mediated through release of $\mathrm{NO}$ and/or other vasodilators from the endothelium. IGF-I stimulates NO release from cultured endothelial cells [20], vascular smooth muscle cells [21] as well as aortic preparations [13]. Pre-treatment with the NO-synthase inhibitor L-NAME is capable of abolishing the vasodilatory effect of IGF-I in large arteries [12, 22-24]. There are also reports of eicosanoids as mediators of the vasodilating effects of IGF-I and that indomethacin may prevent vasodilatation by IGF-I [22, 24, 25]. Moreover, IGF-I may cause vasorelaxation through non-endothelium-dependent actions [26], possibly by increasing the activity of the $\mathrm{Na}^{+}, \mathrm{K}^{+}$-ATPase in vascular smooth muscle cells [27]. Another possible mechanism for the GH/IGF-I influence on vascular tone involves the regulation of gene expression of the vascular smooth muscle $\mathrm{K}_{\mathrm{ATP}}$ channel [28]. This ATP sensitive potassium channel consists of two subunits, the inwardly rectifying potassium channel Kir6 1 and the sulfonylurea receptor 2B (SUR2B) [29] where Kir6 1 has been proposed to be critical for regulation of vascular tone [30]. Moreover, the smooth muscle $\mathrm{K}_{\mathrm{ATP}}$ channel is also the target for the anti-hypertensive potassium channel opening drugs [29]. GH treatment of hypophysectomized $(\mathrm{hx})$ rats resulted in increased mRNA levels of both Kir6 1 and SUR2B, and this was correlated to a lowering of systolic blood pressure [28].
Central effects

It has also been suggested that some vasoactive effects of $\mathrm{GH}$ may have central origin. In a comparison between GH-deficient (GHD) patients without GH substitution and healthy controls matched for BMI, it was shown that GHD patients had markedly increased muscle sympathetic nerve activity [3]. Moreover, 1 year of substitution therapy with $\mathrm{GH}$ had a modest but significant effect on decreasing sympathetic nerve activity to the muscle vascular bed [31]. This could suggest that GH may regulate the central sympathetic outflow affecting peripheral resistance.

\section{Vascular consequences of GHD}

Conflicting results regarding blood pressure and peripheral resistance have been reported in the literature, although it appears that at least in certain patients, GH treatment can lower peripheral resistance. In GH-deficient adults without GH replacement therapy, an increased prevalence of hypertension was reported in a large study that mainly consisted of adult-onset GH-deficient patients [32]. However, unchanged blood pressure has also been reported [33] and in studies mainly consisting of young GH-deficient adults, even reduced blood pressure has been reported [3436]. In another study, GH replacement therapy did not affect systolic blood pressure, whereas diastolic blood pressure was decreased due to reduced peripheral vascular resistance [37]. Also in men with the metabolic syndrome but without severe GH deficiency, a lowering of diastolic blood pressure was observed after $\mathrm{GH}$ treatment for 9-months [38]. A stimulatory effect of GH on nitric oxide production [39] could possibly explain the reduced peripheral vascular resistance and the reduction in diastolic blood pressure in response to $\mathrm{GH}$ supplementation that have been observed in some trials. However, there are also studies showing unchanged [40] or even increased [41] blood pressure during GH replacement. Taken together, it can be speculated that $\mathrm{GH}$ replacement reduces blood pressure only in subgroups of GH-deficient adults, possibly in patients with high base-line diastolic blood pressure [42], such as GH-deficient patients with previous Cushinǵs disease or elderly GH-deficient adults.

Atherosclerosis has also been observed in hypopituitary adults without $\mathrm{GH}$ replacement therapy. In a study by Markussis et al. [33], increased carotid artery wall thickness was observed in GH-deficient adults. The results of several later studies suggest that $\mathrm{GH}$ replacement may reverse early atherosclerotic changes in the carotid arteries in GH-deficient adults [43, 44]. 


\section{Vasculature in GH excess}

It would appear that more short-term exposure to high levels of GH leads to a decrease of peripheral resistance. Some pioneering experimental studies focusing on the hemodynamic effects of chronic GH hypersecretion employed a rat model with an implantable GH-secreting tumor was used as an experimental model [45]. These rats displayed cardiomegaly and increased cardiac contractility and output, while peripheral resistance was decreased [45]. In human acromegalics, three stages of cardiovascular disease have been identified-an early, intermediate and late stage of the disease [1]. Interestingly, although rarely diagnosed in the early stage, patients with only a relatively short duration of acromegaly display a "hyperkinetic" cardiovascular system with increased cardiac output and decreased total peripheral resistance [1]. However, if the disease is not treated, it progresses into more advanced stages with hypertension as a common finding. Hypertension has been reported in the bGH mouse model [46] and in humans, studies suggest a prevalence of hypertension of $20-50 \%$ in acromegalic patients [47]. The mechanisms for the increased prevalence of hypertension have been suggested to include an expansion of plasma volume, stimulation of smooth muscle cell growth leading to increased vascular resistance, and increased insulin resistance as a potential facilitator of increased blood pressure (for review see: [48]).

The prevalence of atherosclerosis in acromegalic patients is controversial. However, recent studies suggest that acromegalic patients do not have increased prevalence of coronary artery disease $[49,50]$, carotid atherosclerosis, or carotid internal media thickness compared to normal subjects [49, 51]. In a recent European study on 200 acromegalic patients matched with a control group, it was reported that patients with active acromegaly had significantly lower levels of high-sensitive C-reactive protein (hsCRP) both compared with patients with controlled acromegaly and with a matched reference population [52]. Possibly, a lower hs-CRP may be linked to lower than expected prevalence of atherosclerosis in patients with active acromegaly, despite the presence of other risk factors such as insulin resistance and hypertension.

\section{Effects of GH and IGF-I on cardiac structure}

Growth and development

It is generally difficult to demonstrate in vitro effects of $\mathrm{GH}$, and consequently, many studies have failed to show direct, IGF-I-independent hypertrophic effects of GH on cardiomyocytes [53, 54]. However, it has been suggested that GH may cause alterations in cardiomyocyte metabolism and stimulate cardiac growth independently of IGF-I $[55,56]$. When performing in vitro studies, it is easier to see effects of IGF-I compared to GH, and many studies have shown that IGF-I increases protein synthesis [53, 57] and the size of cardiomyocytes [54] in vitro.

Several genes have been identified as targets of GH and IGF-I, and it has previously been shown that IGF-I stimulates the expression of muscle-specific genes in rat cardiomyocytes [54]. In hx rats, GH and IGF-I treatment stimulated similar cardiac gene expression (skeletal a-actin, atrial natriuretic factor) but neither IGF-I nor GH caused a shift of myosin heavy chain isoforms [58]. Interestingly, it has been shown that expression of activated calcineurin mimics the hypertrophic effects of IGF-I in skeletal muscle [59].

Cardiac hypertrophy requires concomitant remodeling of the heart, and attention has been focused on the role of the extracellular matrix in the remodeling process [60]. It has been shown that IGF-I promotes collagen synthesis by fibroblasts [61] and that GH increases the collagen deposition rate in the heart [62], while in GH-induced hypertrophy, the volume fraction of collagen is normal [63, 64]. Thus, available data are in line with an increased synthesis as well as breakdown of extracellular matrix with a finally unchanged cardiac collagen concentration by $\mathrm{GH}$.

Besides obvious growth promoting effects on cardiomyocytes, GH and IGF-I may also modulate the structure of the myocardium by preventing cardiomyocyte loss through apoptosis. Ongoing apoptosis has been demonstrated also in the normal heart [65], and there is substantial evidence that IGF-I acts as an inhibitor of apoptosis. In line with this, it has been proposed that an anti-apoptotic effect GH/IGF-I may serve to protect the myocardium in conditions with ischemic injury [66, 67]. However, although an increased number of nuclei in the heart of GH-treated adult rats have been reported [64], there is still no evidence that GH or IGF-I can affect cardiomyocyte number in the normal heart unless overexpressed from the embryonic cell stage [68].

\section{Cardiac structure in GHD}

A number of studies have addressed cardiac structure in patients lacking GH. It has been reported that GH-deficient adults without $\mathrm{GH}$ replacement therapy have reduced left ventricular mass and cardiac output [34] and decreased exercise capacity [1]. The results of some studies suggest that the cardiac dysfunction may be more severe in GHdeficient patients with childhood-onset disease than in patients with adult-onset disease due to the lack of GH/ IGF-I during growth and development of the heart [34]. In a study by Longobardi et al. [69], however, patients with 
childhood- and adult-onset disease younger than 40 years of age were studied using equilibrium radionucleotide angiography. In this study, left ventricular ejection fraction was decreased by $17 \%$ at rest and $29 \%$ at peak exercise as compared with age- and sex-matched controls without any difference between childhood- and adult-onset disease [69].

Short-term and placebo-controlled studies have shown that $\mathrm{GH}$ replacement therapy in adult $\mathrm{GH}$-deficient patients has an anabolic effect on cardiac structure [35, 37, 70], resulting in an improvement in both diastolic [71], and systolic [35, 37, 70, 72] function. A few open label studies have determined the long-term effects of $\mathrm{GH}$ replacement therapy on cardiac function. Thirty-eight months of GH replacement therapy normalized cardiac structure, whereas heart rate and cardiac index increased to supranormal levels [73]. In another study, including 38 young men with childhood-onset $\mathrm{GH}$ deficiency, GH replacement therapy for 55 months (range 39-69) increased stroke volume and maximal exercise capacity without any long-term increase in left ventricular mass [41].

In 7 adults with adult-onset GH deficiency, 42 months of open $\mathrm{GH}$ treatment increased the left ventricular mass and decreased the atrial emptying index, which reflects diastolic function, as compared with healthy matched controls [74]. The results of this last study might suggest, although a higher dose of GH was given than that used today, that increased age might increase the susceptibility to develop inappropriate increment in left ventricular mass during long-term GH replacement therapy. Therefore, studies so far suggest that low dose, individualized $\mathrm{GH}$ replacement therapy improves cardiac function with less risk of developing cardiac hypertrophy. This may explain, combined with the increased muscle strength, the improved exercise capacity in $\mathrm{GH}$-deficient adults observed after $\mathrm{GH}$ replacement. However, if an inappropriately high dose of $\mathrm{GH}$ is given, there is a risk of an unwanted increment in left ventricular mass, particularly in elderly GH-deficient patients during long-term treatment.

\section{Cardiac structure in acromegaly}

Acromegaly is usually a slowly progressing disease where gradually signs of changes in cardiac structure and function develop in a considerable number of patients. Advanced acromegalic cardiomyopathy is characterized by cardiomegaly, ventricular hypertrophy, replacement fibrosis, and degeneration of cardiomyocytes [47, 75]. The precise mechanism for this gradual decline in cardiac structure is not known. However, transgenic mice overexpressing bGH were also found to have deterioration in myocardial bioenergetics that was linked to ultrastructural changes in mitochondria and depression of systolic function [76].
Treatment strategies for acromegaly include surgery and pharmacological options, mainly with long-acting somatostatin analogs, a GH-antagonist and dopamine agonists. In therapy resistant cases, radiotherapy may also be an additional option. It has been reported that both surgery and pharmacological treatments with a decrease in $\mathrm{GH}$ and IGF-I levels lead to improvement in cardiac structure and function (for review see [48].

\section{GH/IGF-I and contractility}

The notion of GH and IGF-I as molecules endowed with stimulatory properties on myocardial contractility is interesting but so far, only demonstrated in experimental studies. In line with reports on cardiac hypertrophy, there are several in vitro studies demonstrating direct effects of IGFI on intrinsic cardiac contractility [77-79], while there is still so far no evidence of direct, IGF-I-independent effects of $\mathrm{GH}$ on cardiac contractility. However, if animals are treated with GH in vivo, allowing stimulation of IGF-I synthesis, subsequent in vitro assessment shows improved contractility [80, 81]. Accordingly, decreased contractility has been demonstrated in dwarf rats with GH/IGF-I deficiency [82-84]. In contrast, a paradoxical enhancement of cardiac contractility was observed in the IGF-I mutant mouse [18].

At least three different mechanisms have been suggested for the GH/IGF-I to induce increased cardiac contractility: 1. altered intracellular $\mathrm{Ca}^{2+}$ transients, 2. increased sensitivity of myofilaments to $\mathrm{Ca}^{2+}$, and 3 . a shift in myosin isoforms.

Regarding intracellular Ca-transients, IGF-I has been shown to acutely affect $\mathrm{Ca}^{2+}$ currents within the cardiomyocyte, with increased peak $\mathrm{Ca}^{2+}$ levels $[78,85]$ and an altered time course of the current [78] in association with increased contractility. Specifically, the activity of L-type $\mathrm{Ca}^{2+}$-channels was acutely increased by IGF-I in vitro [86]. In cardiomyocytes from acromegalic rats, the action potential duration was increased due to a decrease in density of a transient outward current carried by $\mathrm{K}^{+}$, which, in turn prolongs the $\mathrm{Ca}^{2+}$-influx through L-type $\mathrm{Ca}^{2+}$-channels [87]. In contrast to other in vitro studies, the acute increase of inotropy by IGF-I was associated with decreased peak $\mathrm{Ca}^{2+}$ levels but increased $\mathrm{Ca}^{2+}$ sensitivity of the contractile elements in isolated whole heart preparations [79]. No influence of $\mathrm{GH}$ on $\mathrm{Ca}^{2+}$ currents has been seen in acute settings [79, 85], while after more long-term treatment in vivo, $\mathrm{GH}$ has been suggested to increase peak intracellular $\mathrm{Ca}^{2+}$ levels measured ex vivo [80, 81]. Accordingly, reduced peak intracellular $\mathrm{Ca}^{2+}$ levels as well as slowed intracellular $\mathrm{Ca}^{2+}$-clearing have been demonstrated in GH/IGF-I deficiency [84], while others report 
peak intracellular $\mathrm{Ca}^{2+}$ levels to be unchanged in GH/IGFI deficiency [83].

To date, little has been known about possible gene regulations involved in the action of GH/IGF-I in altering $\mathrm{Ca}^{2+}$ handling. An up-regulation of sarcoplasmic reticulum ATPase (SERCA) levels has been suggested to contribute to the increased contractile function elicited by GH after myocardial infarction [81] and in rapid pacing heart failure [88], while another study [89] has not been able to detect any change in SERCA expression. SERCA may increase contractility by enhancement of the so-called contractile reserve, i.e., the $\mathrm{Ca}^{2+}$ storage within the sarcoplasmic reticulum, allowing higher peak $\mathrm{Ca}^{2+}$ levels upon stimulation. Ueyama et al. [90] also suggested that GH treatment in cardiomyopathic, but not normal, hamsters preserved cardiac ryanodine receptor density.

Myofilament $\mathrm{Ca}^{2+}$-sensitivity and myosin isoform shift. GH/IGF-I has been suggested to increase myofilament $\mathrm{Ca}^{2+}$ sensitivity $[79,84,91]$ and maximum $\mathrm{Ca}^{2+}$ activated force [79, 80, 91]. However, data are conflicting, and others report unchanged [85] or even decreased [80] myofilament $\mathrm{Ca}^{2+}$ sensitivity by GH/IGF-I. In dwarf rats, unchanged myofilament $\mathrm{Ca}^{2+}$ sensitivity has been reported [83, 84], although maximum $\mathrm{Ca}^{2+}$ activated tension was less [83]. In animal models of GH excess, a shift toward a myosin isoform with lower ATPase activity has been demonstrated, which may decrease the energy demand of the contractile process [91, 92].

Taken together, available data suggest that GH/IGF-I may increase cardiac contractility through modulations of intracellular $\mathrm{Ca}^{2+}$ transients, myofilament $\mathrm{Ca}^{2+}$ sensitivity, and myosin isoform expression, although the findings depend upon different experimental settings and among studies. Besides regulation of ion channel activity, GH/ IGF-I may also regulate the expression of ion channels. Solid evidence for increased contractility by GH and IGF-I is still lacking.

\section{Cardiovascular aspects of GHD}

\section{Cardiovascular risk factors}

In addition to the cardiac dysfunction, several cardiovascular risk factors are associated with adult GH deficiency. These include insulin resistance [93, 94], unfavorable alterations in serum lipid pattern including increased serum low density lipoprotein (LDL)-cholesterol concentration [95], decreased fibrinolysis [96], and increased sympathetic nervous activity [3]. Other cardiovascular risk factors beneficially affected by GH treatment include homocysteine and C-reactive protein (for review see: [97]). In addition, pregnancy-associated plasma protein-A (PAPP-A) has been found to be elevated in GHD patients [98]. This may be of particular interest, since PAPP-A is both a cardiovascular risk factor and a mediator of IGF-I bioavailability [98]. Body composition has a tendency to deteriorate in hypopituitary adults with increased body fat and decreased body cell mass [99]. Furthermore, extracellular water is decreased, [32], which may result in reduced preload of the heart (Starling effect). Finally, decreased sweating, impaired thermoregulation, and increased risk for developing hyperthermia during exercise in hot environments [100] have been observed in GH-deficient adult patients.

GH replacement therapy normalizes most of the cardiovascular risk factors observed in hypopituitary patients [101]. Body composition is rapidly normalized by GH replacement therapy [95] and appears to be partly sustained after 15 years of therapy [102]. Aberrations in serum lipid concentrations and fibrinolysis are also improved by $\mathrm{GH}$ replacement therapy $[95,103]$. A modest improvement of sympathetic nerve activity was found after 1 year of $\mathrm{GH}$ replacement [31]. The effects by GH replacement on insulin sensitivity are still controversial [104, 105], although in one study, 7-year GH replacement provided protection from the age-related decline in insulin sensitivity [105].

\section{Morbidity and mortality}

A landmark retrospective study by Rosén and Bengtsson [32] showed doubled overall mortality due to increased cardiovascular mortality in hypopituitary adults, as compared with the normal population. The hypopituitary patients in the study by Rosén and Bengtsson [32] had routine hormonal replacement therapy which did not include GH at that time. Two additional retrospective studies [106, 107], and one prospective study [108], have confirmed that the increase in total mortality in hypopituitary adults without GH replacement therapy is due to increased cardiovascular mortality. A more recent study was based on data recorded by the Board of Health and Welfare in Sweden [109]. This study confirmed an increased overall mortality in 1,411 hypopituitary patients without GH replacement therapy [109]. The increase in the total number of myocardial infarctions (fatal and non-fatal) was less marked than the increase in cerebrovascular events in this study [109]. The risk ratio for myocardial infarction in the hypopituitary patients without $\mathrm{GH}$ replacement therapy was $1.40,95 \%$ CI 1.10-1.75.

There is no abundance of data regarding the effect of GH replacement therapy on cardiovascular morbidity and mortality. In the report by Svensson et al. [109], there was, however, also a prospective study of 289 hypopituitary patients that received GH replacement therapy at a single center. The mean duration of GH treatment was 60 months 
(range 2-118 months). It was demonstrated that the risk ratio for myocardial infarctions was even lower in the 289 hypopituitary patients on GH replacement therapy than in the general population. Taking into account that the relative risk of myocardial infarctions was increased in hypopituitary patients without $\mathrm{GH}$ replacement, the reduced rate of myocardial infarctions in hypopituitary on $\mathrm{GH}$ replacement therapy clearly indicates that $\mathrm{GH}$ replacement therapy will be effective in preventing myocardial infarctions in hypopituitary adults. In a recent prospective observational study on GH-deficient adults from the US on $1988 \mathrm{GH}-$ treated patients and 442 untreated and a mean follow-up for 2.3 years, there was no increase in overall mortality rate or cardiovascular events between the two studied groups [110]. However, the follow-up was comparatively short which makes conclusion on long-term effects uncertain.

\section{A potential therapeutic role for $\mathrm{GH}$ in heart failure?}

Despite considerable advances in both medication strategies and use of medical devices in patients with heart failure in the last decades, the prognosis is still poor, and there is a continued interest to develop alternative or additional treatment modalities.

One of the first clinical publications to mention possible beneficial effects of $\mathrm{GH}$ in heart failure was the paper by Caidahl et al. [37] in 1994, describing improvement in systolic function in GH-deficient patients treated with $\mathrm{GH}$.

This triggered several research groups to study effects of GH and/or IGF-I in experimental models with states of impaired cardiac function. In an established rat model of congestive heart failure following ligation of the left coronary artery, GH and IGF-I have been found to increase stroke volume and cardiac output [111, 112], also in the presence of ACE inhibition [113]. GH treatment of rats with experimental myocardial infarction has also been found to improve myocardial bioenergetics [114] and longterm survival [115].

The first clinical studies regarding GH treatment in heart failure were limited to case reports [116, 117] where $\mathrm{GH}$ administration dramatically improved cardiac function. A subsequent small open study of seven patients with idiopathic dilated cardiomyopathy and $\mathrm{CHF}$ without $\mathrm{GH}$ deficiency, who received GH treatment for 3 months, demonstrated considerable improvement of left ventricular ejection fraction, cardiac output, and exercise performance [118]. Further studies have demonstrated beneficial effects in patients with $\mathrm{CHF}$ due to both ischemic and idiopathic dilated cardiomyopathy with improvements in hemodynamics when $\mathrm{GH}$ was added both as a maintenance therapy and as short-term infusion [119, 120]. Moreover, another interesting observation was that patients with a low base- line serum IGF-I had less beneficial effects of an acute GH infusion [121]. A later study showed that GH treatment decreased circulating levels of cytokines such as TNF- $\alpha$ and IL-6 and apoptotic agents such as FAS and its soluble ligand in patients with heart failure [122].

Even though a more recent placebo-controlled trial on 16 patients with $\mathrm{CHF}$ showed correction of endothelial dysfunction and improved non-endothelium dependent vasodilation [123], other randomized, placebo-controlled studies have failed so far to show any significant $\mathrm{GH}$ mediated improvement of cardiac performance in patients with heart failure, despite significant increases in IGF-I [124, 125]. However, in a follow-up study of the same patients in the former study, analyzed in more depth, Perrot et al. [126], found a significant increase in left ventricular mass, which correlated with serum IGF-I. Moreover, there was a significant increase of ejection fraction in those patients that responded with higher serum IGF-I levels during GH treatment. Acevedo et al. [127] performed a randomized controlled trial of 19 patients with daily $\mathrm{GH}$ administration for 8 weeks. However, at the end of treatment, there was no significant effect of GH on LVEF or peak oxygen consumption, although left ventricular mass was reported to be increased.

The prevalence of cardiac cachexia in patients with chronic congestive heart failure has been uncertain. However, in a recent study, it was estimated to be $10.5 \%$ in a population of 238 patients with stable congestive heart failure [128]. Importantly, cardiac cachexia in severe heart failure could lead to a number of endocrine disturbances [129], including acquired GH resistance and may explain some of the diverse responses to $\mathrm{GH}$ therapy observed in different patients [130].

The reasons for the lack of convincing positive effects of $\mathrm{GH}$ on cardiac function in these randomized trials in all likelihood depend upon several factors. Duration of treatment has been relatively short (2-3 months) compared to conventional heart failure trials, and the studies have so far included only a small number of patients, which may also contribute to lack of power and negative results. Encouragingly, a meta-analysis encompassing 12 clinical trials still suggested that GH treatment had beneficial effects on left ventricular geometry, ejection fraction, and exercise parameters, all correlated to increase in serum IGF-I levels [131]. Hence, whether GH treatment will finally find a place in the treatment of heart failure remains to be established and need to be studied in larger placebo-controlled clinical trials.

A topic which has received increased attention during the last years is the endocrine status of heart failure patients. It has been suggested that multiple anabolic deficiencies are common in heart failure patients and that this may be associated with worse outcome [132-134]. At 
present, the literature is inconsistent regarding the GH/IGFI axis in heart failure describing both low levels of IGF-I $[133,135,136]$ and normal or even higher levels [137]. Possible explanations for these diverging results may be due to heterogeneous heart failure patients and the use of different IGF-I assays. Even less is known about GH secretion in heart failure, although there are indications of disturbed secretion [138]. A more recent study suggests that as many as $40 \%$ may fulfill criteria for GH deficiency [139].

Recently, a novel approach in the selection of heart failure patients to be treated with GH was taken by the group of Saccà and collaborators. Using a GH provocation test, only patients that fulfilled criteria for GH deficiency $(n=56)$ were enrolled in a randomized, single blind study where they were treated with GH for 6 months. Here, GH had a number of beneficial effects compared to controls, including improved quality of life score, increased peak oxygen uptake, exercise duration, and flow-mediated vasodilation. Moreover, GH treatment leads to a moderate but significant increase in left ventricular ejection fraction and a reduction in circulating $N$-terminal pro-brain natriuretic peptide levels [139]. Future studies with more robust RCT design are needed to verify the validity of this approach of selecting heart failure patients for GH. However, preliminarily, results so far are very promising.

\section{Summary and conclusions}

It can be summarized that $\mathrm{GH}$ appears to have a number of important effects, both on the heart and the vasculature. Furthermore, an intact GH/IGF-I system with neither deficiency nor excess appears to be optimal for a normal cardiovascular function. Anabolic impairment in heart failure, including possible GH deficiency, opens up interesting perspectives for new treatment modalities with hormones in addition to conventional heart failure in the future.

Open Access This article is distributed under the terms of the Creative Commons Attribution License which permits any use, distribution, and reproduction in any medium, provided the original author(s) and the source are credited.

\section{References}

1. L. Sacca, A. Cittadini, S. Fazio, Growth hormone and the heart. Endocr. Rev. 15, 555-573 (1994)

2. J. Ren, W.K. Samson, J.R. Sowers, Insulin-like growth factor I as a cardiac hormone: physiological and pathophysiological implications in heart disease. J. Mol. Cell. Cardiol. 31, 2049-2061 (1999)

3. Y. Sverrisdóttir, M. Elam, B.-Å. Bengtsson, G. Johannsson, Intense sympathetic nerve activity in adults with hypopituitarism and untreated growth hormone deficiency. J. Clin. Endocrinol. Metab. 83, 1881-1885 (1998)

4. J. Isgaard, A. Nilsson, K. Vikman, O.G. Isaksson, Growth hormone regulates the level of insulin-like growth factor-I mRNA in rat skeletal muscle. J. Endocrinol. 120, 107-112 (1989)

5. A.J. D'Ercole, A.D. Stiles, L.E. Underwood, Tissue concentrations of somatomedin C: further evidence for multiple sites of synthesis and paracrine or autocrine mechanisms of action. Proc. Natl. Acad. Sci. USA 81, 935-939 (1984)

6. P. Delafontaine, K.E. Bernstein, R.W. Alexander, Insulin-like growth factor I gene expression in vascular cells. Hypertension 17, 693-699 (1991)

7. L.S. Mathews, B. Enberg, G. Norstedt, Regulation of rat growth hormone receptor gene expression. J. Biol. Chem. 264, 9905-9910 (1989)

8. J. Isgaard, H. Wåhlander, M.A. Adams, P. Friberg, Increased expression of growth hormone receptor mRNA and insulin-like growth factor-I mRNA in volume-overloaded hearts. Hypertension 23, 884-888 (1994)

9. A. Wickman, P. Friberg, M.A. Adams, G.L. Matejka, C. Brantsing, G. Guron, J. Isgaard, Induction of growth hormone receptor and insulin-like growth factor-I mRNA in aorta and caval vein during hemodynamic challenge. Hypertension 29 . 123-130 (1997)

10. H.P. Guler, J. Zapf, E. Scheiwiller, E.R. Froesch, Recombinant human insulin-like growth factor I stimulates growth and has distinct effects on organ size in hypophysectomized rats. Proc. Natl. Acad. Sci. USA 85, 4889-4893 (1988)

11. A. Wickman, J. Isgaard, M.A. Adams, P. Friberg, Inhibition of nitric oxide in rats. Regulation of cardiovascular structure and expression of insulin-like growth factor I and its receptor messenger RNA. J. Hypertens. 15, 751-759 (1997)

12. G. Pete, Y. Hu, M. Walsh, J. Sowers, J.C. Dunbar, Insulin-like growth factor-I decreases mean blood pressure and selectively increases regional blood flow in normal rats. Proc. Soc. Exp. Biol. Med. 213, 187-192 (1996)

13. M.F. Walsh, M. Barazi, G. Pete, R. Muniyappa, J.C. Dunbar, J.R. Sowers, Insulin-like growth factor I diminishes in vivo and in vitro vascular contractility: role of vascular nitric oxide. Endocrinology 137, 1798-1803 (1996)

14. M.Y. Donath, R. Jenni, H.P. Brunner, M. Anrig, S. Kohli, Y. Glatz, E.R. Froesch, Cardiovascular and metabolic effects of insulin-like growth factor $I$ at rest and during exercise in humans. J. Clin. Endocrinol. Metab. 81, 4089-4094 (1996)

15. M.Y. Donath, G. Sutsch, X.W. Yan, B. Piva, H.P. Brunner, Y. Glatz, J. Zapf, F. Follath, E.R. Froesch, W. Kiowski, Acute cardiovascular effects of insulin-like growth factor I in patients with chronic heart failure. J. Clin. Endocrinol. Metab. 83, 3177-3183 (1998)

16. F. Manelli, M. Volterrani, R. Lorusso, G. Romanelli, A. Giustina, Acute growth hormone effects in human subjects with heart failure, in Growth Hormone and the Heart, ed. by A. Giustina (Kluwer Academic, Boston, 2001), pp. 87-96

17. R. Napoli, V. Guardasole, V. Angelini, F. DAmico, E. Zarra, M. Matarazzo, L. Saccà, Acute effects of growth hormone on vascular function in human subjects. J. Clin. Endocrinol. Metab. 88, 2817-2820 (2003)

18. G. Lembo, H.A. Rockman, J.J. Hunter, H. Steinmetz, W.J. Koch, L. Ma, M.P. Prinz, J. Ross Jr, K.R. Chien, L. PowellBraxton, Elevated blood pressure and enhanced myocardial contractility in mice with severe IGF-1 deficiency. J. Clin. Invest. 98, 2648-2655 (1996)

19. Å. Tivesten, E. Bollano, I. Andersson, S. Fitzgerald, K. Caidahl, K. Sjögren, O. Skøtt, J.-L. Liu, D. LeRoith, R. Mobini, O.G.P. Isaksson, J.-O. Jansson, C. Ohlsson, G. Bergström, J. Isgaard, Liver-derived insulin-like growth factor-I is involved in the 
regulation of blood pressure in nice. Endocrinology 143, 4235-4242 (2002)

20. H. Tsukahara, D.V. Gordienko, B. Tonshoff, M.C. Gelato, M.S. Goligorsky, Direct demonstration of insulin-like growth factorI-induced nitric oxide production by endothelial cells. Kidney Int. 45, 598-604 (1994)

21. R. Muniyappa, M.F. Walsh, J.S. Rangi, R.M. Zayas, P.R. Standley, J.L. Ram, J.R. Sowers, Insulin like growth factor 1 increases vascular smooth muscle nitric oxide production. Life Sci. 61, 925-931 (1997)

22. J. Haylor, I. Singh, A.M. el Nahas, Nitric oxide synthesis inhibitor prevents vasodilation by insulin-like growth factor I. Kidney Int. 39, 333-335 (1991)

23. D.A. Fryburg, NG-monomethyl-L-arginine inhibits the blood flow but not the insulin-like response of forearm muscle to IGFI: possible role of nitric oxide in muscle protein synthesis. J. Clin. Invest. 97, 1319-1328 (1996)

24. C.L. Oltman, N.L. Kane, D.D. Gutterman, R.S. Bar, K.C. Dellsperger, Mechanism of coronary vasodilation to insulin and insulin-like growth factor I is dependent on vessel size. Am. J. Physiol. Endocrinol. Metab. 279, E176-E181 (2000)

25. R. Hirschberg, J.D. Kopple, Evidence that insulin-like growth factor I increases renal plasma flow and glomerular filtration rate in fasted rats. J. Clin. Invest. 83, 326-330 (1989)

26. D. Hasdai, R.A. Rizza, D.R. Holmes Jr, D.M. Richardson, P. Cohen, A. Lerman, Insulin and insulin-like growth factor-I cause coronary vasorelaxation in vitro. Hypertension 32, 228-234 (1998)

27. P.R. Standley, F. Zhang, R.M. Zayas, R. Muniyappa, M.F. Walsh, E. Cragoe, J.R. Sowers, IGF-I regulation of $\mathrm{Na}(+)-$ $\mathrm{K}(+)$-ATPase in rat arterial smooth muscle. Am. J. Physiol. 273, E113-E121 (1997)

28. Å. Tivesten, A. Barlind, K. Caidahl, N. Klintland, A. Cittadini, C. Ohlsson, J. Isgaard, J. Endocrinol. 183, 195-202 (2004)

29. A. Fujita, Y. Kurachi, Molecular aspects of ATP sensitive $\mathrm{K}^{+}$ channels in the cardiovascular system and $\mathrm{K}^{+}$channel openers. Pharmacol. Ther. 85, 39-53 (2000)

30. T. Miki, M. Suzuki, T. Shibasaki, H. Uemura, T. Sato, K. Yamaguchi, H. Koseki, T. Iwanaga, H. Nakaya, S. Seino, Mouse model of prinzmetal angina by disruption of the inward rectifier Kir6 1. Nat. Med. 8, 466-472 (2002)

31. Y. Sverrisdottir, M. Elam, K. Caidahl, A.S. Söderling, H. Herlitz, G. Johannsson, The effect of growth hormone $(\mathrm{GH})$ replacement therapy on sympathetic nerve hyperactivity in hypopituitary adults: a double-blind, placebo-controlled, crossover, short-term trial followed by long-term open GH replacement in hypopituitary adults. J. Hypertens. 10, 1905-1914 (2003)

32. T. Rosén, S. Edén, G. Larsson, L. Wilhelmsen, B.-Å. Bengtsson, Cardiovascular risk factors in adult patients with growth hormone deficiency. Acta Endocrinol. 129, 195-200 (1993)

33. V. Markussis, S. Beshyah, C. Fisher, P. Sharp, A. Nicolaides, D. Johnston, Detection of premature atherosclerosis by high-resolution ultrasonography in symptom-free hypopituitary adults. Lancet 340, 1188-1192 (1992)

34. A. Cittadini, A. Cuocolo, B. Merola, S. Fazio, D. Sabatini, E. Nicolai, A. Colao, S. Longobardi, G. Lombardi, L. Sacca, Impaired cardiac performance in GH-deficient adults and its improvement after GH replacement. Am. J. Physiol. 267, E219E225 (1994)

35. G. Amato, C. Carella, S. Fazio, G. La Montagna, A. Cittadini, D. Sabatini, C. Marciano-Mone, L. Sacca, A. Bellastella, Body composition, bone metabolism, and heart structure and function in growth hormone $(\mathrm{GH})$-deficient adults before and after $\mathrm{GH}$ replacement therapy at low doses. J. Clin. Endocrinol. Metab. 77, 1671-1676 (1993)
36. S. Fazio, A. Cittadini, D. Sabatini, B. Merola, A. Colao, B. Biondi, S. Longobardi, G. Lombardi, L. Sacca, Growth hormone and heart performance. A novel mechanism of cardiac wall stress regulation in humans. Eur. Heart J. 18, 340-347 (1997)

37. K. Caidahl, S. Edén, B.-Å. Bengtsson, Cardiovascular and renal effects of growth hormone. Clin. Endocrinol. 40, 93-400 (1994)

38. G. Johannsson, P. Mårin, L. Lönn, M. Ottosson, K. Stenlöf, P. Björntorp, L. Sjöström, B.-^̊. Bengtsson, GH treatment of abdominally obese men reduces abdominal fat mass, improves glucose and lipoprotein metabolism, and reduces diastolic blood pressure. J. Clin. Endocrinol. Metab. 82, 727-734 (1997)

39. R. Böger, C. Skamira, S. Bode-Böger, G. Brabant, A. von zur Mühlen, J. Frölich, Nitric oxide may mediate the hemodynamic effects of recombinant growth hormone in patients with acquired growth hormone deficiency. J. Clin. Invest. 98, 2706-2713 (1996)

40. G. Götherström, J. Svensson, J. Koranyi, M. Alpsten, I. Bosæus, B.-A. Bengtsson, G. Johannsson, A prospective study of five years of growth hormone $(\mathrm{GH})$ replacement therapy in $\mathrm{GH}$ deficient adults; sustained effects on body composition, bone mass, and metabolic indices. J. Clin. Endocrinol. Metab. 86, 4657-4665 (2001)

41. J. ter Maaten, H. de Boer, O. Kamp, L. Stuurman, E. van der Veen, Long-term effects of growth hormone $(\mathrm{GH})$ replacement in men with childhood-onset GH deficiency. J. Clin. Endocrinol. Metab. 84, 2373-2380 (1999)

42. G. Johannsson, K. Sunnerhagen, J. Svensson, Baseline characteristics and the effects of two years of growth hormone $(\mathrm{GH})$ replacement therapy in adults with GH deficiency previously treated for Cushinǵs disease. Clin. Endocrinol. 60, 550-559 (2004)

43. F. Borson-Chazot, A. Serusclat, Y. Kalfallah, X. Ducottet, G. Sassolas, S. Bernard, F. Labrousse, J. Pastene, A. Sassolas, Y. Roux, F. Berthezene, Decrease in carotid intima-media thickness after one year growth hormone $(\mathrm{GH})$ treatment in adults with GH deficiency. J. Clin. Endocrinol. Metab. 84, 1329-1333 (1999)

44. M. Pfeifer, M. Verhovec, B. Zizek, J. Prezelj, P. Poredos, R.N. Clayton, Growth hormone $(\mathrm{GH})$ treatment reverses early atherosclerotic changes in GH-deficient adults. J. Clin. Endocrinol. Metab. 84, 453-457 (1999)

45. D.G. Penney, J.C. Dunbar Jr, M.S. Baylerian, Cardiomegaly and haemodynamics in rats with a transplantable growth hormonesecreting tumour. Cardiovasc. Res. 19, 270-277 (1985)

46. Y.M. Bohlooly, L. Carlson, B. Olsson, H. Gustafsson, I.J. Andersson, J. Törnell, G. Bergström, Vascular function and blood pressure in GH transgenic mice. Endocrinology 142, 3317-3323 (2001)

47. M. Losa, K. von Werder, The heart in acromegaly, in Growth Hormone and the Heart, ed. by A. Giustina (Kluwer Academic, Boston, 2001), pp. 33-43

48. S. Mosca, S. Paolillo, A. Colao, E. Bossone, A. Cittadini, F.L. Ludice, A. Parente, S. Conte, G. Rengo, D. Leosco, B. Trimarco, P.P. Filardi, Cardiovascular involvement in patients affected by acromegaly: an appraisal. Int. J. Cardiol. 167, 1712-1718 (2013)

49. F. Bogazzi, L. Battolla, C. Spinelli, G. Rossi, S. Gavioli, V. Di Bello, C. Cosci, C. Sardella, D. Volterrani, E. Talini, P. Pepe, F. Falaschi, G. Mariani, E. Martino, Risk factors for development of coronary artery disease in patients with acromegaly: a fiveyear prospective study. J. Clin. Endocrinol. Metab. 92, 42714277 (2007)

50. H. Akutsu, J. Kreutzer, G. Wasmeier, D. Ropers, C. Rost, M. Möhlig, H. Wallaschofski, M. Buchfelder, C. Schöfl, Acromegaly per se does not increase the risk for coronary artery disease. Eur. J. Endocrinol. 162, 879-886 (2010) 
51. M. Otsuki, S. Kasayama, H. Yamamoto, H. Saito, S. Sumitani, H. Kouhara, Y. Saitoh, T. Ohnishi, N. Arita, Characterization of premature atherosclerosis of carotid arteries in acromegalic patients. Clin. Endocrinol. 54, 791-796 (2001)

52. J. Verhelst, B. Velkeniers, D. Maiter, P. Haentjens, G. T́Sjoen, G. Rietzschel, B. Corvilain, P. Abrams, F. Nobels, R. Abs, M. Bex, Active acromegaly is associated with decreased hs-CRP and NT-proBNP serum levels: insights from the Belgian registry of acromegaly. Eur. J. Endocrinol. 168, 177-184 (2013)

53. M.Y. Donath, J. Zapf, M. Eppenberger-Eberhardt, E.R. Froesch, H.M. Eppenberger, Insulin-like growth factor I stimulates myofibril development and decreases smooth muscle alpha-actin of adult cardiomyocytes. Proc. Natl. Acad. Sci. USA 91, 1686-1690 (1994)

54. H. Ito, M. Hiroe, Y. Hirata, M. Tsujino, S. Adachi, M. Shichiri, A. Koike, A. Nogami, F. Marumo, Insulin-like growth factor-I induces hypertrophy with enhanced expression of muscle specific genes in cultured rat cardiomyocytes. Circulation 87, 1715-1721 (1993)

55. P. Schnabel, F. Mies, T. Nohr, M. Geisler, M. Bohm, Differential regulation of phospholipase C-beta isozymes in cardiomyocyte hypertrophy. Biochem. Biophys. Res. Commun. 275, $1-6(2000)$

56. C. Lu, G. Schwartzbauer, M.A. Sperling, S.U. Devaskar, S. Thamotharan, P.D. Robbins, C.F. McTiernan, J.L. Liu, J. Jiang, S.J. Frank, R.K. Menon, Demonstration of direct effects of growth hormone on neonatal cardiomyocytes. J. Biol. Chem. 276, 22892-22900 (2001)

57. S.J. Fuller, J.R. Mynett, P.H. Sugden, Stimulation of cardiac protein synthesis by insulin-like growth factors. Biochem. J. 282(Pt 1), 85-90 (1992)

58. M.Y. Donath, M.A. Gosteli-Peter, C. Hauri, E.R. Froesch, J. Zapf, Insulin-like growth factor-I stimulates myofibrillar genes and modulates atrial natriuretic factor mRNA in rat heart. Eur. J. Endocrinol. 137, 309-315 (1997)

59. A. Musaro, K.J. McCullagh, F.J. Naya, E.N. Olson, N. Rosenthal, IGF-1 induces skeletal myocyte hypertrophy through calcineurin in association with GATA-2 and NF-ATc1. Nature 400, 581-585 (1999)

60. E.E. Creemers, J.P. Cleutjens, J.F. Smits, M.J. Daemen, Matrix metalloproteinase inhibition after myocardial infarction: a new approach to prevent heart failure? Circ. Res. 89, 201-210 (2001)

61. R.P. Butt, G.J. Laurent, J.E. Bishop, Collagen production and replication by cardiac fibroblasts is enhanced in response to diverse classes of growth factors. Eur. J. Cell Biol. 68, 330-335 (1995)

62. A. Bruel, H. Oxlund, Biosynthetic growth hormone increases the collagen deposition rate in rat aorta and heart. Eur. J. Endocrinol. 132, 195-199 (1995)

63. A. Cittadini, H. Stromer, S.E. Katz, R. Clark, A.C. Moses, J.P. Morgan, P.S. Douglas, Differential cardiac effects of growth hormone and insulin-like growth factor- 1 in the rat. A combined in vivo and in vitro evaluation. Circulation 93, 800-809 (1996)

64. A. Bruel, H. Oxlund, J.R. Nyengaard, Growth hormone increases the total number of myocyte nuclei in the left ventricle of adult rats. Growth Horm. IGF Res. 12, 106-115 (2002)

65. J. Kajstura, W. Cheng, R. Sarangarajan, P. Li, B. Li, J.A. Nitahara, S. Chapnick, K. Reiss, G. Olivetti, P. Anversa, Necrotic and apoptotic myocyte cell death in the aging heart of Fischer 344 rats. Am. J. Physiol. 271, H1215-H1228 (1996)

66. Q. Li, B. Li, X. Wang, A. Leri, K.P. Jana, Y. Liu, J. Kajstura, R. Baserga, P. Anversa, Overexpression of insulin-like growth factor-1 in mice protects from myocyte death after infarction, attenuating ventricular dilation, wall stress, and cardiac hypertophy. J. Clin. Invest. 100, 1991-1999 (1997)
67. M. Buerke, T. Murohara, C. Skurk, C. Nuss, K. Tomaselli, A.M. Lefer, Cardioprotective effect of insulin-like growth factor I in myocardial ischemia followed by reperfusion. Proc. Natl. Acad. Sci. USA 92, 8031-8035 (1995)

68. K. Reiss, W. Cheng, A. Ferber, J. Kajstura, P. Li, B. Li, G. Olivetti, C.J. Homcy, R. Baserga, P. Anversa, Overexpression of insulin-like growth factor-1 in the heart is coupled with myocyte proliferation in transgenic mice. Proc. Natl. Acad. Sci. USA 93, 8630-8635 (1996)

69. S. Longobardi, A. Cuocolo, B. Merola, F. Di Rella, A. Colao, E. Nicolai, S. Cardei, M. Salvatore, G. Lombardi, Left ventricular function in young adults with childhood and adulthood onset growth hormone deficiency. Clin. Endocrinol. 48, 137-143 (1998)

70. R. Cuneo, F. Salomon, C. Wiles, R. Hesp, P. Sönksen, Growth hormone treatment in growth hormone-deficient adults. II. Effects on exercise performance. J. Appl. Physiol. 70, 695-700 (1991)

71. S. Beshyah, M. Shahi, E. Skinner, P. Sharp, R. Foale, D. Johnston, Cardiovascular effects of growth hormone replacement therapy in hypopituitary adults. Eur. J. Endocrinol. 130, 451-458 (1994)

72. S. Fort, J. Weaver, J. Monson, P. Mills, The effects of low dose recombinant human growth hormone on cardiovascular structure and function in hypopituitary adults growth hormone-deficient adults. Endocrinol. Metab. 2, 119-126 (1995)

73. L. Thuesen, J. Jørgensen, J. Müller, B. Kristensen, N. Skakkebæk, N. Vahl, J.S. Christiansen, Short and long-term cardiovascular effects of growth hormone therapy in growth hormone deficient adults. Clin. Endocrinol. 41, 615-620 (1994)

74. G. Johannsson, B.- $\AA$. Bengtsson, B. Andersson, J. Isgaard, K. Caidahl, Long-term cardiovascular effects of growth hormone treatment in GH-deficient adults. Preliminary data in a small group of patients. Clin. Endocrinol. 45, 305-314 (1996)

75. L. Saccà, R. Napoli, A. Cittadini, Growth hormone, acromegaly and heart failure: an intricate triangulation. Clin. Endocrinol. 59, 660-671 (2003)

76. E. Bollano, E. Omerovic, M. Bohlooly-y, V. Kujacic, B. Madhu, J. Tornell, O. Isaksson, B. Soussi, W. Schulze, M.L. Fu, G. Matejka, F. Waagstein, J. Isgaard, Impairment of cardiac function and bioenergetics in adult transgenic mice overexpressing the bovine growth hormone gene. Endocrinology 141, 2229-2235 (2000)

77. U. Vetter, C. Kupferschmid, D. Lang, S. Pentz, Insulin-like growth factors and insulin increase the contractility of neonatal rat cardiocytes in vitro. Basic Res. Cardiol. 83, 647-654 (1988)

78. N.S. Freestone, S. Ribaric, W.T. Mason, The effect of insulinlike growth factor-1 on adult rat cardiac contractility. Mol. Cell. Biochem. 163-164, 223-229 (1996)

79. A. Cittadini, Y. Ishiguro, H. Strömer, M. Spindler, A.C. Moses, R. Clark, P.S. Douglas, J.S. Ingwall, J.P. Morgan, Insulin-like growth factor-1 but not growth hormone augments mammalian myocardial contractility by sensitizing the myofilament to $\mathrm{Ca}^{2+}$ through a wortmannin-sensitive pathway: studies in rat and ferret isolated muscles. Circ. Res. 83, 50-59 (1998)

80. H. Strömer, A. Cittadini, P.S. Douglas, J.P. Morgan, Exogenously administered growth hormone and insulin-like growth factor-I alter intracellular $\mathrm{Ca}^{2+}$ handling and enhance cardiac performance. In vitro evaluation in the isolated isovolumic buffer-perfused rat heart. Circ. Res. 79, 227-236 (1996)

81. M. Tajima, E.O. Weinberg, J. Bartunek, H. Jin, R. Yang, N.F. Paoni, B.H. Lorell, Treatment with growth hormone enhances contractile reserve and intracellular calcium transients in myocytes from rats with postinfarction heart failure. Circulation 99, 127-134 (1999) 
82. A. Cittadini, H. Strömer, D.E. Vatner, J.D. Grossman, S.E. Katz, R. Clark, J.P. Morgan, P.S. Douglas, Consequences of growth hormone deficiency on cardiac structure, function, and betaadrenergic pathway: studies in mutant dwarf rats. Endocrinology 138, 5161-5169 (1997)

83. H. Strömer, A. Cittadini, J.D. Grossman, P.S. Douglas, J.P. Morgan, Intrinsic cardiac muscle function, calcium handling and beta -adrenergic responsiveness is impaired in rats with growth hormone deficiency. Growth Horm. IGF Res. 1999(9), 262-271 (1999)

84. J. Ren, H. Brown-Borg, Impaired cardiac excitation-contraction coupling in ventricular myocytes from Ames dwarf mice with IGF-I deficiency. Growth Horm. IGF Res. 12, 99-105 (2002)

85. S. Kinugawa, H. Tsutsui, T. Ide, R. Nakamura, K. Arimura, K. Egashira, A. Takeshita, Positive inotropic effect of insulin-like growth factor- 1 on normal and failing cardiac myocytes. Cardiovasc. Res. 43, 157-164 (1999)

86. M.L. Solem, A.P. Thomas, Modulation of cardiac $\mathrm{Ca}^{2+}$ channels by IGF-1. Biochem. Biophys. Res. Commun. 252, 151-155 (1998)

87. X.P. Xu, P.M. Best, Decreased transient outward $\mathrm{K}^{+}$current in ventricular myocytes from acromegalic rats. Am. J. Physiol. 260, H935-H942 (1991)

88. W.V. Houck, L.C. Pan, S.B. Kribbs, M.J. Clair, G.M. McDaniel, R.S. Krombach, W.M. Merritt, C. Pirie, J.P. Iannini, R. Mukherjee, F.G. Spinale, Effects of growth hormone supplementation on left ventricular morphology and myocyte function with the development of congestive heart failure. Circulation 100, 2003-2009 (1999)

89. H. Jin, R. Yang, H. Lu, A.K. Ogasawara, W. Li, A. Ryan, F. Peale, N.F. Paoni, Effects of early treatment with growth hormone on infarct size, survival, and cardiac gene expression after acute myocardial infarction. Growth Horm. IGF Res. 12, 208-215 (2002)

90. T. Ueyama, T. Ohkusa, M. Yano, M. Matsuzaki, Growth hormone preserves cardiac sarcoplasmic reticulum $\mathrm{Ca}^{2+}$ release channels (ryanodine receptors) and enhances cardiac function in cardiomyopathic hamsters. Cardiovasc. Res. 40, 64-73 (1998)

91. E. Mayoux, R. Ventura-Clapier, J. Timsit, F. Behar-Cohen, C. Hoffmann, J.J. Mercadier, Mechanical properties of rat cardiac skinned fibers are altered by chronic growth hormone hypersecretion. Circ. Res. 72, 57-64 (1993)

92. J. Timsit, B. Riou, J. Bertherat, C. Wisnewsky, N.S. Kato, A.S. Weisberg, J. Lubetzki, Y. Lecarpentier, S. Winegrad, J.J. Mercadier, Effects of chronic growth hormone hypersecretion on intrinsic contractility, energetics, isomyosin pattern, and myosin adenosine triphosphatase activity of rat left ventricle. J. Clin. Invest. 86, 507-515 (1990)

93. J.-O. Johansson, J. Fowelin, K. Landin, I. Lager, B.-Å. Bengtsson, Growth hormone-deficient adults are insulin-resistant. Metabolism 44, 1126-1129 (1995)

94. F. Hew, M. Koschmann, M. Christopher, C. Rantzau, A. Vaag, G. Ward, H. Beck-Nielsen, F. Alford, Insulin resistance in growth hormone-deficient adults: defects in glucose utilization and glycogen synthase activity. J. Clin. Endocrinol. Metab. 81, 555-564 (1996)

95. W. Drake, S. Howell, J. Monson, S. Shalet, Optimizing GH therapy in adults and children. Endocr. Rev. 22, 425-450 (2001)

96. J.-O. Johansson, K. Landin, L. Tengborn, T. Rosén, B.-Å. Bengtsson, High fibrinogen and plasminogen activator inhibitor activity in growth hormone-deficient adults. Arterioscler. Thromb. 14, 434-437 (1994)

97. M. Gola, S. Bonadonna, M. Doga, A. Giustina, Clinical review. Growth hormone and cardiovascular risk factors. J. Clin. Endocrinol. Metab. 90(3), 1864-1870 (2005)
98. L. Li, W. Ren, J. Li, Increase in serum pregnancy-associated plasma protein-A is correlated with increase in cardiovascular risk factors in adult patients with growth hormone deficiency. Endocrine 42(2), 375-381 (2012)

99. T. Rosén, I. Bosaeus, J. Tölli, G. Lindstedt, B.-Å. Bengtsson, Increased body fat mass and decreased extracellular fluid volume in adults with growth hormone deficiency. Clin. Endocrinol. 38, 63-71 (1993)

100. A. Juul, N. Hjortskov, L. Jepsen, B. Nielsen, J. Halkjaer-Kristensen, N. Vahl, J.O. Jørgensen, J.S. Christiansen, N. Skakkebaek, Growth hormone deficiency and hyperthermia during exercise: a controlled study of sixteen GH-deficient patients. J. Clin. Endocrinol. Metab. 80, 3335-3340 (1995)

101. C. Gazzaruso, M. Gola, I. Karamouzis, R. Giubbini, A. Giustina, Cardiovascular risk in adult patients with growth hormone $(\mathrm{GH})$ deficiency and following substitution with $\mathrm{GH}$ : an update. J. Clin. Endocrinol. Metab. 99(1), 18-29 (2014)

102. M. Elbornsson, G. Götherström, I. Bosaeus, B.-Å. Bengtsson, G. Johannsson, J. Svensson, Fifteen years of growth hormone replacement improves body composition and cardiovascular risk factors. Eur. J. Endocrinol. 168, 745-753 (2013)

103. J.-O. Johansson, K. Landin, G. Johannsson, L. Tengborn, B.-Å. Bengtsson, Long-term treatment with growth hormone decreases plasminogen activator inhibator-I and tissue plasminogen activator in growth hormone-deficient adults. Thromb. Haemost. 76, 422-428 (1996)

104. M. Christopher, F. Hew, M. Oakley, C. Rantzau, F. Alford, Defects of insulin action and skeletal muscle glucose metabolism in growth hormone-deficient adults persist after 24 months of recombinant human growth hormone therapy. J. Clin. Endocrinol. Metab. 83, 1668-1681 (1998)

105. J. Svensson, J. Fowelin, K. Landin, B.-Å. Bengtsson, J.-O. Johansson, Effects of 7 years of GH-replacement therapy on insulin sensitivity in GH-deficient adults. J. Clin. Endocrinol. Metab. 87, 2121-2127 (2002)

106. B. Bülow, L. Hagmar, Z. Mikoczy, C. Nordström, E. Erfurth, Increased cerebrovascular mortality in patients with hypopituitarism. Clin. Endocrinol. 46, 75-81 (1997)

107. A. Bates, W. Vańt Hoff, P. Jones, R. Clayton, The effect of hypopituitarism on life expectancy. J. Clin. Endocrinol. Metab. 81, 1169-1172 (1996)

108. J. Tomlinson, N. Holden, R. Hills, K. Wheatley, R. Clayton, A. Bates, M. Sheppard, P. Stewart, Association between premature mortality and hypopituitarism. West Midlands Prospective Hypopituitary Study Group. Lancet 357, 425-431 (2001)

109. J. Svensson, B.-Å. Bengtsson, T. Rosén, A. Odén, G. Johannson, The incidence of malignant disease and cardiovascular morbidity in hypopituitary patients with or without growth hormone replacement therapy. J. Clin. Endocrinol. Metab. 89, 3306-3312 (2004)

110. M. Hartman, R. Xu, B.J. Crowe, L.L. Robison, E.M. Erfurth, D.L. Kleinberg, A.G. Zimmermann, W.W. Woodmansee, G.B. Cutler Jr, J.J. Chipman, S.S. Melmed, International HypoCCS Advisory Board: prospective safety surveillance of GH-deficient adults: comparison of GH-treated vs untreated patients. J. Clin. Endocrinol. Metab. 98, 980-988 (2013)

111. R. Yang, S. Bunting, N. Gillett, R. Clark, H. Jin, Growth hormone improves cardiac performance in experimental heart failure. Circulation 92, 262-267 (1995)

112. J. Isgaard, V. Kujacic, E. Jennische, A. Holmäng, X.Y. Sun, T. Hedner, A. Hjalmarson, B.-A. Bengtsson, Growth hormone improves cardiac function in rats with experimental myocardial infarction. Eur. J. Clin. Invest. 27, 517-525 (1997)

113. H. Jin, R. Yang, N. Gillett, R.G. Clark, A. Ko, N.F. Paoni, Beneficial effects of growth hormone and insulin-like factor-1 in 
experimental heart failure in rats treated with chronic ACE inhibition. J. Cardiovasc. Pharmacol. 26, 420-425 (1995)

114. E. Omerovic, R. Fahrami, M. Basetti, B. Soussi, A. Hjalmarson, F. Waagstein, J. Isgaard, Growth hormone improves bioenergetics and decreases catecholamines in postinfarct rat hearts. Endocrinology 141, 4592-4599 (2000)

115. A. Cittadini, J. Isgaard, M.G. Monti, C. Casaburi, A.D. Di Gianni, R. Serpico, L. Saccà, Growth hormone prolongs survival and attenuates interstitial remodeling in postinfarction heart failure. J. Am. Coll. Cardiol. 41, 2154-2163 (2003)

116. R.C. Cuneo, P. Wilmshurst, C. Lowy, G. McGauley, P.H. Sönksen, Cardiac failure responding to growth hormone. Lancet 1, 838-839 (1989)

117. A. Frustaci, G.A. Perrone, N. Gentiloni, M.A. Russo, Reversible dilated cardiomyopathy due to growth hormone deficiency. Am. J. Clin. Pathol. 97, 503-511 (1992)

118. S. Fazio, D. Sabatini, B. Capaldo, C. Vigorito, A. Giordano, R. Guida, F. Pardo, B. Biondi, L. Sacca, A preliminary study of growth hormone in the treatment of dilated cardiomyopathy. N. Engl. J. Med. 334, 809-814 (1996)

119. S. Genth-Zotz, R. Zotz, S. Geil, T. Voigtlander, J. Meyer, H. Darius, Recombinant growth hormone therapy in patients with ischemic cardiomyopathy. Effects on hemodynamics, left ventricular function and cardiopulmonary exercise capacity. Circulation 99, 18-21 (1999)

120. M. Volterrani, P. Desenzani, R. Lorusso, A. d'Aloia, F. Manelli, A. Giustina, Haemodynamic effects of intravenous growth hormone in congestive heart failure. Lancet 349, 1067-1068 (1997)

121. A. Giustina, M. Volterrani, F. Manelli, P. Desenzani, C. Poiesi, R. Lorusso, A. Giordano, Endocrine predictors of acute hemodynamic effects of growth hormone in congestive heart failure. Am. Heart J. 137(6), 1035-1043 (1999)

122. S. Adamopoulos, J.T. Parissis, M. Georgiadis, D. Karatzas, I. Paraskevaid, C. Kroupis, G. Karavolias, K. Koniavitou, D.T. Kremastinos, Growth hormone administration reduces circulating proinflammatory cytokines and soluble Fas/soluble Fas ligand system in patients with chronic heart failure secondary to idiopathic dilated cardiomyopathy. Am. Heart J. 144, 359-364 (2002)

123. R. Napoli, V. Guardasole, M. Matarazzo, E.A. Palmieri, U. Oliviero, S. Fazio, L. Sacca, Growth hormone corrects vascular dysfunction in patients with chronic heart failure. J. Am. Coll. Cardiol. 39, 90-95 (2002)

124. K.J. Osterziel, O. Strohm, J. Schuler, M. Friedrich, D. Hanlein, R. Willenbrock, S.D. Anker, P.A. Poole-Wilson, M.B. Ranke, R. Dietz, Randomised, double-blind, placebo-controlled trial of human recombinant growth hormone in patients with chronic heart failure due to dilated cardiomyopathy. Lancet 351, 1233-1237 (1998)

125. J. Isgaard, C.H. Bergh, K. Caidahl, M. Lomsky, A. Hjalmarson, B.A. Bengtsson, A placebo-controlled study of growth hormone in patients with congestive heart failure. Eur. Heart J. 19, 1704-1711 (1998)

126. A. Perrot, M.B. Ranke, R. Dietz, K.J. Osterziel, Growth hormone treatment in dilated cardiomyopathy. J. Card. Surg. 16, 127-131 (2001)
127. M. Acevedo, R. Corbalán, G. Chamorro, J. Jalil, C. Nazzal, C. Campusano, P. Castro, Administration of growth hormone to patients with advanced cardiac heart failure: effects upon left ventricular function, exercise capacity and neurohormonal status. Int. J. Cardiol. 87, 185-191 (2003)

128. H.M. Christensen, C. Kistorp, M. Schou, N. Keller, B. Zerahn, J. Frystyk, P. Schwarz, J. Faber, Prevalence of cachexia in chronic heart failure and characteristics of body composition and metabolic status. Endocrine 43(3), 626-634 (2013)

129. N. Mangner, Y. Matsuo, G. Schuler, V. Adams, Cachexia in chronic heart failure: endocrine determinants and treatment perspectives. Endocrine 43, 253-265 (2013)

130. S.D. Anker, M. Volterrani, C.D. Pflaum, C.J. Strasburger, K.J. Osterziel, W. Doehner, M.B. Ranke, P.A. Poole-Wilson, A. Giustina, R. Dietz, A.J. Coats, Acquired growth hormone resistance in patients with chronic heart failure: implications for therapy with growth hormone. J. Am. Coll. Cardiol. 38, 443-452 (2001)

131. P. Le Corvoisier, L. Hittinger, P. Chanson, O. Montagne, I. Macquin-Mavier, P. Maison, Cardiac effects of growth hormone treatment in chronic heart failure: a meta-analysis. J. Clin. Endocrinol. Metab. 92, 180-185 (2007)

132. L. Sacca, Heart failure as a multiple hormonal deficiency syndrome. Circ Heart Fail. 2, 151-156 (2009)

133. E.A. Jankowska, B. Biel, J. Majda, A. Szklarska, M. Lopuszanska, M. Medras, S.D. Anker, W. Banasiak, P.A. PooleWilson, P. Ponikowski, Anabolic deficiency in men with chronic heart failure: prevalence and detrimental impact on survival. Circulation 114, 1829-1837 (2006)

134. M. Volterrani, G. Rosano, F. Iellamo, Testosterone and heart failure. Endocrine 42(2), 272-277 (2012)

135. F. Broglio, A. Benso, C. Gottero, L.D. Vito, G. Aimaretti, A. Fubini, E. Arvat, M. Bobbio, E. Ghigo, Patients with dilated cardiomyopathy show reduction of the somatotroph responsiveness to GHRH both alone and combined with arginine. Eur. J. Endocrinol. 142, 157-163 (2000)

136. P.E. Kontoleon, M.I. Anastasiou-Nana, P.D. Papapetrou, G. Alexopoulos, V. Ktenas, A.C. Rapti, E.P. Tsagalou, J.N. Nanas, Hormonal profile in patients with congestive heart failure. Int. J. Cardiol. 87, 179-183 (2003)

137. S. Watanabe, T. Tamura, K. Ono, H. Horiuchi, T. Kimura, T. Kita, Y. Furukawa, Insulin-like growth factor axis (insulin-like growth factor-I/insulin-like growth factor-binding protein-3) as a prognostic predictor of heart failure: association with adiponectin. Eur. J. Heart Fail. 12, 1214-1222 (2010)

138. A. Giustina, R. Lorusso, V. Borghetti, G. Bugari, V. Misitano, O. Alfieri, Impaired spontaneous growth hormone secretion in severe dialated cardiomyopathy. Am. Heart J. 131, 620-622 (1996)

139. A. Cittadini, L. Saldamarco, A.M. Marra, M. Arcopinto, G. Carlomagno, M. Imbriaco, D. Del Forno, C. Vigorito, B. Merola, U. Oliviero, S. Fazio, L. Sacca, Growth hormone deficiency in patients with chronic heart failure and beneficial effects of its correction. J. Clin. Endocrinol. Metab. 94, 3329-3336 (2009) 